\title{
Induced Breeding of Fresh Water Angelfish (Pterophyllum Scalare) Using Ova prim
}

\author{
N.R.Chatterjee ${ }^{1}$, Samiran Patra ${ }^{2}$ and N.A.Talwar ${ }^{3}$ \\ ${ }^{1,2}$ (Department of Aquaculture., Faculty of Fishery Sciences, India) $^{3}$ (Department of Fishery Engineering, \\ Faculty of Fishery Sciences, India) West Bengal University of Animal and Fishery Sciences 5, Budherhat Road, \\ Panchasayar, Kolkata- 700094
}

\begin{abstract}
Induced spawning experiments on fresh water angelfish, Pterophyllum scalare was carried out for the first time using Ovaprim (sGnRH+ Domperidone). The optimum dose of Ovaprim $(0.35 \mathrm{ml} / \mathrm{kg}$ of body weight) was standardized based on three experiments, viz., fecundity (relative fecundity) at different doses ( $r=-$ 0.94; $p<0.01, n=6)$, response time (hrs) at various doses and fertilization rate $(r=-0.69 ; p<0.01 ; n=6)$ at different doses. Maximum fecundity (665.66) obtained at the dose of $0.35 \mathrm{ml} / \mathrm{kg}$ of body weight and a significant relation was observed between doses and response time (hrs.) of spawning at $1 \%$ level $(F=189.14 ; p<0.01 ; n$ $=6)$. Lower breeding response time recorded at this dose.
\end{abstract}

Keywords: Angelfish, Induced breeding, Fecundity, Fertilization rate and Response time

\section{Introduction}

Angelfish (Pterophyllum scalare) native to Amazon region of South America is a cichlid fish and fetch a great demand due to its beauty, reproductive capacity \& adaptability to captivity, as also, the economic potential of this species is also very high. Tropical fish like P. Scalare is new species for aquaculture and is used for hobbies and marketed all over the world.

The environs of India offer vast scope for trapping both fresh water and marine ornamental fish resources, but due to the lack of adequate infrastructure and key inputs like appropriate feed and quality brood stock, these breeding units are not in a position to produce varieties, which are in demand in the international market. The favorable climatic condition, availability of work force required for collection, ease of breeding and rearing, high market demand are the factors that plays an important role to invite people from different sectors opt for culture and propagation of this particular species. In West Bengal, a persistent job and income oriented drift from villages and urban areas resulted in overcrowding in cities and subsequent loss of work force in rural areas (Roy, 1994). In such condition, breeding and culture of ornamental fish may be an additional source of income for the rural mass. Breeding and culture of ornamental fish is a highly lucrative venture that can be an attractive alternative to check such migration (Das, 2003; Chattopadhyay, 2003)

\subsection{Induced breeding:}

\section{Materials \& Methods:}

After selection of healthy mature brooders they were maintained in spawning tank. Only female fish were injected according to their weight. The materials required for injection, included Ovaprim, Insulin syringe ( $1 \mathrm{ml}$ capacity, 40 divisions), Nylon cloth net, Distilled water, and two $250 \mathrm{ml}$ size beakers. In the present study the weight of female varied between $12-15 \mathrm{~g}$ (average $13.96 \mathrm{~g}$ ). As, the Ovaprim requirement was very low and as the prepared amount was very difficult to measure, so a very low dilution of Ovaprim using distilled water was injected. The water parameters of the both rain water and bore well water were

\subsection{Calculation of Ovaprim dose ( $\mathrm{ml} / \mathrm{kg}$ of body weight).}

Syringe of $1 \mathrm{ml}$ capacity having 40 divisions i.e., each unit measures $0.025 \mathrm{ml}$ capacity was selected for convenience. So, 1 unit of Ovaprim is equals to $0.025 \mathrm{ml}$. After taking 1 unit Ovaprim, distilled water was added to make the volume 10 units in the same syringe. Now the concentration of Ovaprim became $0.0025 \mathrm{ml}$ in each unit of the syringe i.e., injection of one unit of diluted Ovaprim will contain $0.0025 \mathrm{ml}$ of Ovaprim suitable for $5 \mathrm{gm}$ female.

\section{Calculation at a glance}

Syringe capacity $=1 \mathrm{ml} ; \quad$ Total no. of divisions in syringe $=40$

Each unit capacity $=1 / 40=0.025 \mathrm{ml}$

So, one unit Ovaprim diluted to10 times $=0.0025 \mathrm{ml}$ Ovaprim/unit.

For example,

Weight of fish: $12 \mathrm{gm}$ 
Recommended dose for injecting Ovaprim is $0.5 \mathrm{ml} / \mathrm{kg}$ body weight of fish

Ovaprim required $=12(0.5 / 1000)=0.006 \mathrm{ml}$

Unit required to inject $=0.006 / 0.0025=2.4$ unit

After taking 1 unit of Ovaprim in syringe it is diluted 10 times with distilled water. Ovaprim requirement was calculated on the basis of the weight of female fish. Ovaprim was injected intramuscularly in between dorsal fin and lateral line and the injected fish released immediately in to the spawning tank. The breeding activities of both the sexes were noted throughout the breeding period.

\section{Experiment 1: Standardization of Ovaprim doses ( $\mathrm{ml} / \mathrm{kg}$ of body weight).}

Different dosages of ovaprim tested:

1) $0.55 \mathrm{ml} / \mathrm{Kg}$ body weight, 2) $0.5 \mathrm{ml} / \mathrm{Kg}$ body weight, 3) $0.45 \mathrm{ml} / \mathrm{Kg}$ body weight, 4) $0.4 \mathrm{ml} / \mathrm{Kg}$ body weight, 5) $0.35 \mathrm{ml} / \mathrm{Kg}$ body weight, 6$) 0.3 \mathrm{ml} / \mathrm{Kg}$ body weight,7) $0.25 \mathrm{ml} / \mathrm{Kg}$ body weight.

The different doses as mentioned yielded different results and the optimum dose was determined based on the three experiments.

1. Fecundity at different doses.

2. Latency period (hrs) with doses.

3. Fertilization rate (\%) in different doses.

\section{Statistical methods used}

All the recorded data and observation were processed and analyzed keeping in view the objectives of the study. The following statistical methods were used in the study: Student's t test (Student's t-test, Fisher/Snedecor's F tests were used to identify differences between treatments) Correlation (Pearson's correlation was used). Statistical tests were performed with MS-Excel software using analysis of variance.
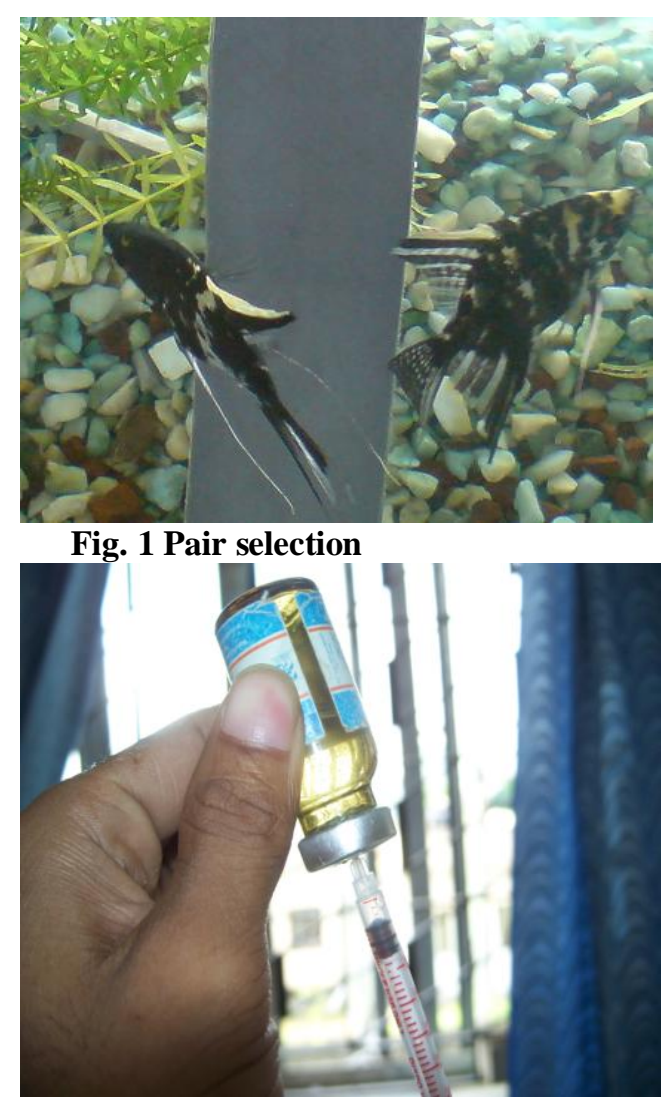

Fig.3 Ovaprim taking into insulin syringe

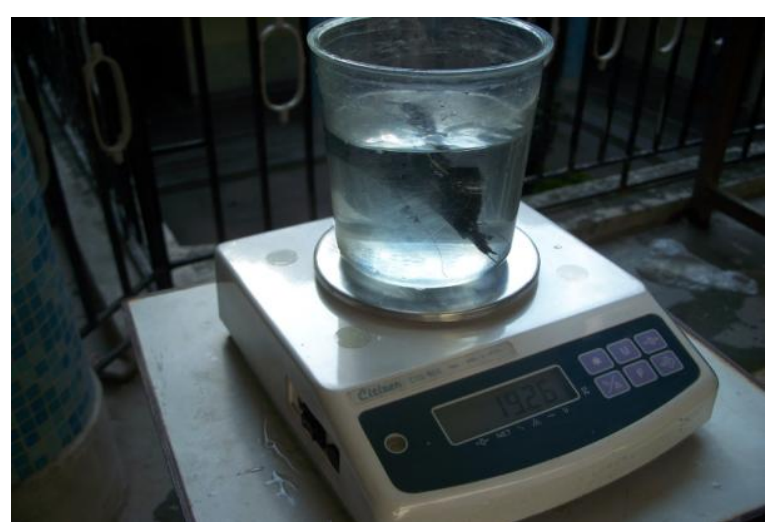

Fig. 2 Taking of fish weight by using Electronic balance.

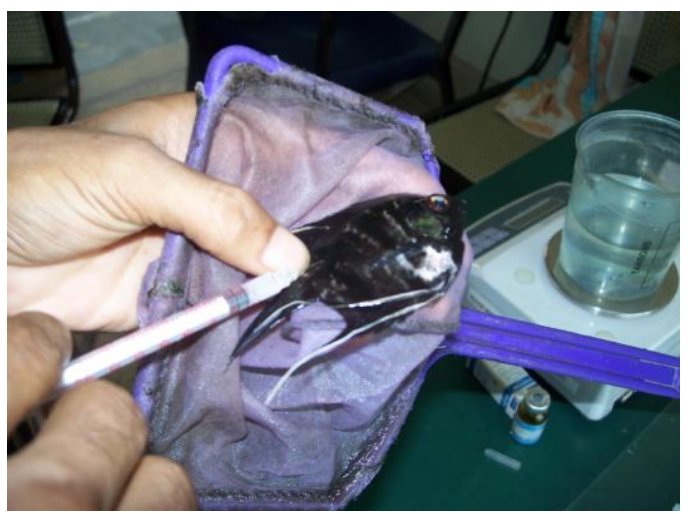

Fig.4 Intramuscular Ovaprim Injection to female 


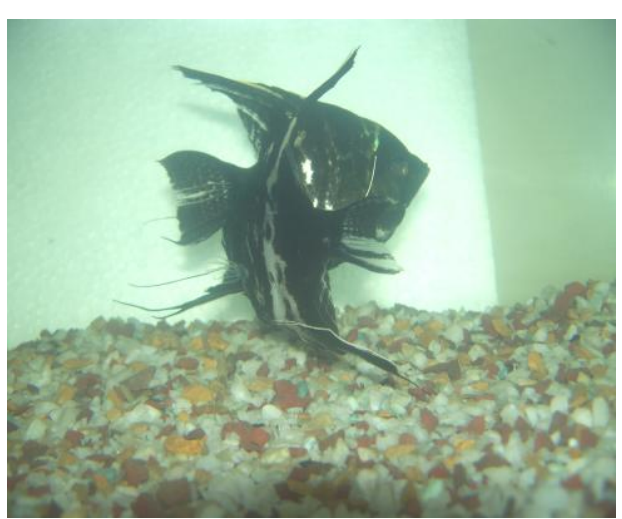

Fig.5 Male and female introduced into spawning tank after injection.

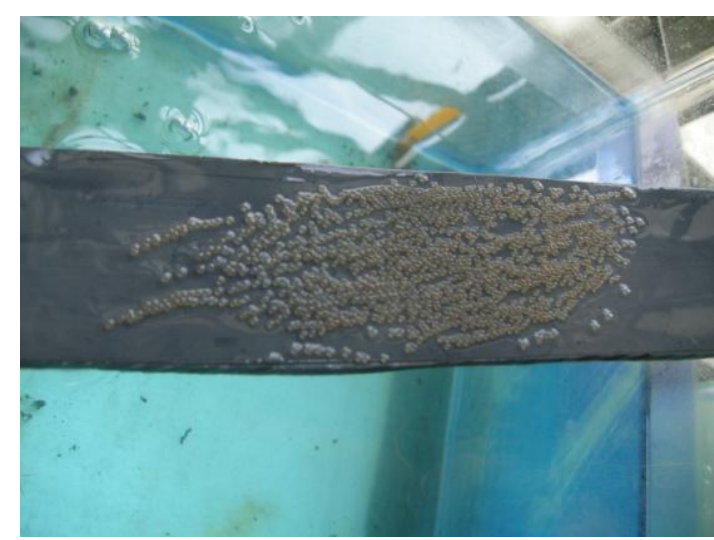

Fig.6 Eggs on plastic scale

\section{Result}

\section{Induced breeding}

\subsection{Dose standardization of process:}

The optimum dose of Ovaprim was standardized on the basis of three experiments, i.e.,

3.1.1 Fecundity in different doses.

3.1.2 Response time (hrs) with doses.

3.1.3. Fertilization rate $(\%)$ in different doses.

3.1.1. Relation between fecundity (No. of eggs) and doses ( $\mathrm{ml} / \mathrm{kg}$ of body weight).

It was observed that, fecundity varied with different doses of Ovaprim (Table 1). The highest and lowest no. of eggs was 665.66 and 30.66 obtained at dose 0.35 and $0.5 \mathrm{ml} / \mathrm{kg}$ of body weight. A negative correlation was observed between relative fecundity and doses significant at $1 \%$ level significance $(r=-0.94 ; p<0.01, n=6)$. There was negative linear relation between relative fecundity and doses show in Fig7.

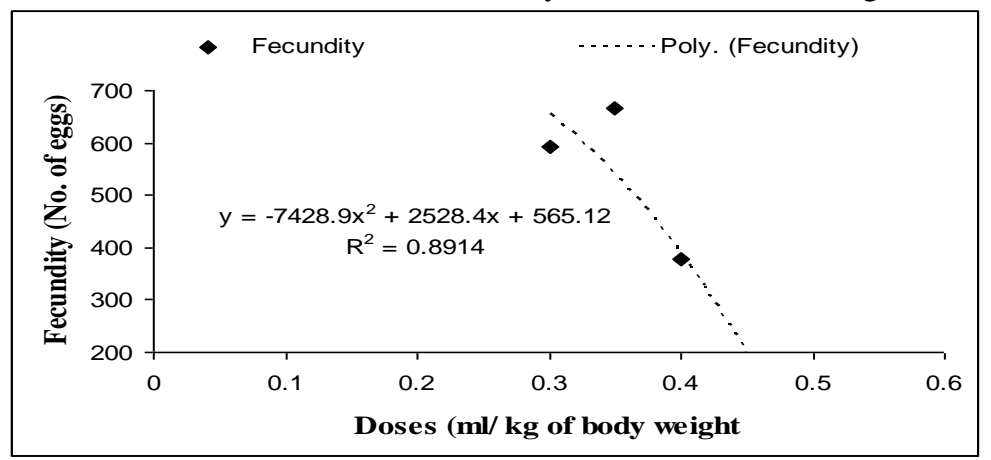

Fig. 7: Correlation between Relative fecundity and doses ( $\mathrm{ml} / \mathrm{kg}$ of body weight).

Table 1: Relation between fecundity (Average fecundity) and doses ( $\mathrm{ml} / \mathrm{kg}$ of body weight; $\mathbf{n}=6$ )

\begin{tabular}{|c|c|}
\hline Doses (ml/kg body weight) & Average fecundity (No. of eggs) \\
\hline 0.55 & 00.00 \\
\hline 0.5 & 30.66 \\
\hline 0.45 & 84.33 \\
\hline 0.4 & 379.33 \\
\hline 0.35 & 665.66 \\
\hline 0.3 & 593.66 \\
\hline
\end{tabular}

3.1.2. Relation between response time of spawning (hr) and doses of Ovaprim ( $\mathrm{ml} / \mathrm{kg}$ of body weight).

In this experiment, it was observed that response time was varied with different doses of Ovaprim ( $\mathrm{ml} / \mathrm{kg}$ of body weight) in Table 2 . A significant relation was observed between doses and response time (hrs.) of spawning at $1 \%$ level $(\mathrm{F}=189.14 ; \mathrm{p}<0.01 ; \mathrm{n}=6)$. Response time was minimum @ $0.40 \mathrm{ml} / \mathrm{kg} \mathrm{of} \mathrm{body}$ weight and maximum time required @ $0.5 \mathrm{ml} / \mathrm{kg}$ of body weight and at $0.55 \mathrm{ml} / \mathrm{kg}$ of body weight there was no spawning occurred in angelfish in Fig. 8. 


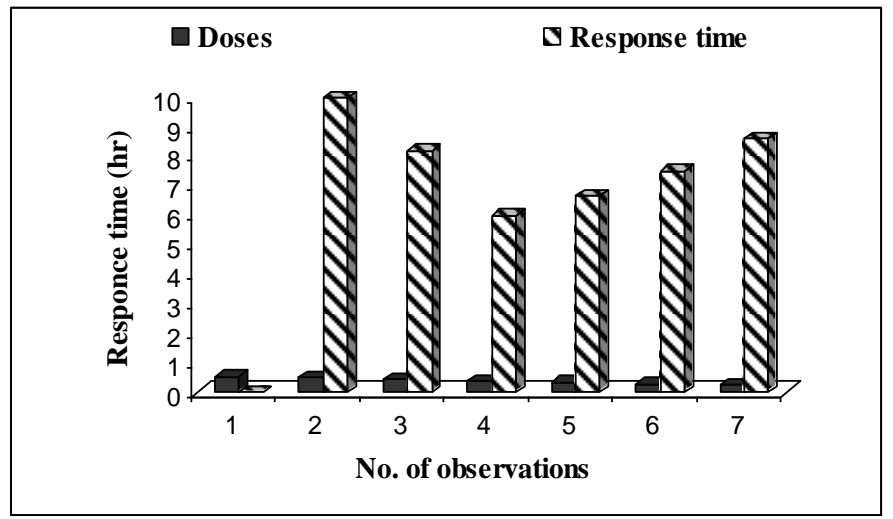

Fig.8 Relation between spawning response ( $\mathrm{hr}$ ) at different doses ( $\mathrm{ml} / \mathrm{kg}$ of body weight)

Table 2: Relation between spawning response time with doses of Ovaprim.

\begin{tabular}{|c|c|c|}
\hline $\begin{array}{c}\text { Doses of Ovaprim } \\
\text { (ml/kg of body weight) }\end{array}$ & $\begin{array}{l}\text { Average } \\
\text { response time } \\
\text { (hr) }\end{array}$ & Characters \\
\hline 0.55 & 0 & $\begin{array}{l}\text { - } \text { Highly stressed } \\
\text { - } \quad \text { Settled down to the bottom } \\
\text { - } \quad \text { Slow movement of fins. } \\
\text { - } \quad \text { No breeding was found. } \\
\text { Within few hours males separated from } \\
\text { females. Male cannot fertilize the eggs. }\end{array}$ \\
\hline 0.5 & 10 & $\begin{array}{l}\text { - } \quad \text { Abnormal behavior was observed } \\
\text { - Come to the bottom, tilting, slow movement } \\
\text { of fins, and stressed. } \\
\text { - Low fertilization rate was very less }(\%)\end{array}$ \\
\hline 0.45 & 8.2 & $\begin{array}{l}\text { - } \quad \text { Abnormal behavior was found. } \\
\text { - } \quad \text { Come to corner of the aquarium. } \\
\text { - } \quad \text { Slowsal and anal fin closed. } \\
\text { - } \quad \text { When female introduced to the breeding tank } \\
\text { male comes to the female, pushing them but } \\
\text { no response from female. } \\
\text { - Lower fertilization rate }(\%)\end{array}$ \\
\hline 0.4 & 6 & 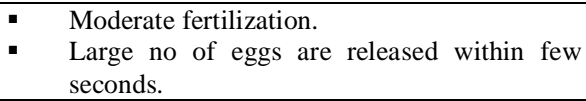 \\
\hline 0.35 & 6.65 & $\begin{array}{ll} & \text { High fertilization rate }(\%) \\
\text { - } & \text { High fecundity } \\
\text { - } & \text { Complete spawning }\end{array}$ \\
\hline 0.3 & 7.5 & - Fertilization rate reduced \\
\hline 0.25 & 8.6 & - Low fertilization rate $(\%)$, less fecundity \\
\hline
\end{tabular}

\subsubsection{Relation between fertilization rate $(\%)$ and doses $(\mathrm{ml} / \mathrm{kg}$ of body weight).}

It was found that fertilization rate (\%) was varied from dose to dose. The highest $(95 \%)$ and lowest (43\%) fertilization rate were obtained at dose of 0.35 ( $\mathrm{ml} / \mathrm{kg}$ of body weight) and $0.5(\mathrm{ml} / \mathrm{kg}$ of body weight) respectively in Table 5. A negative correlation was found between fertilization rate $(\%)$ and doses $(\mathrm{ml} / \mathrm{kg}$ of body weight) at $1 \%$ significant level $(\mathrm{r}=-0.69 ; \mathrm{p}<0.01 ; \mathrm{n}=6)$. Fertilization rate $(\%)$ was increased and decreased above or below the optimum level of Ovaprim dose (ml/kg of body weight) in Fig. 9.

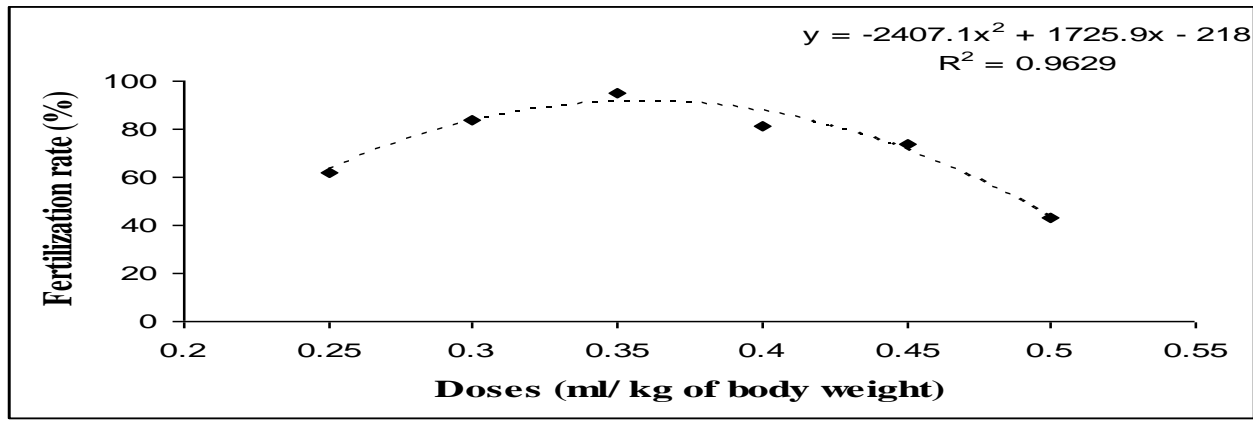

Fig.9 Correlation between fertilization rate $(\%)$ and doses $(\mathrm{ml} / \mathrm{kg}$ of body weight). 
Table 3: Relation between fertilization rate (\%) and doses.

\begin{tabular}{|c|c|}
\hline Doses (ml/kg of body weight) & Fertilization rate (\%) \\
\hline 0.55 & 00 \\
\hline 0.5 & 43 \\
\hline 0.45 & 74 \\
\hline 0.4 & 81 \\
\hline 0.35 & 95 \\
\hline 0.3 & 84 \\
\hline 0.25 & 62 \\
\hline
\end{tabular}

\subsubsection{Standard dose of Ovaprim for angelfish breeding.}

The recommended dose of Ovaprim is @ $0.5 \mathrm{ml} / \mathrm{kg}$ of body weight. Different dosages of Ovaprim were tested: 1) $0.55 \mathrm{ml} / \mathrm{Kg}$ body weight, 2) $0.5 \mathrm{ml} / \mathrm{Kg}$ body weight 3) $0.45 \mathrm{ml} / \mathrm{Kg}$ body weight, 4) $0.4 \mathrm{ml} / \mathrm{Kg}$ body weight, 5) $0.35 \mathrm{ml} / \mathrm{Kg}$ body weight6) $0.3 \mathrm{ml} / \mathrm{Kg}$ body weight and 7) $0.25 \mathrm{ml} / \mathrm{Kg}$ body weight

For the standardization of Ovaprim dose for induced breeding were followed the three experiments, i.e., relation between relative fecundity and doses, response time (hrs.) and doses and the fertilization rate (\%). The differences in results were obtained. On the basis of three experiments got the maximum fecundity, less response time (hrs.), and higher fertilization rate (\%) in $0.35 \mathrm{ml} / \mathrm{kg}$ of body weight in Table 3,4 and 5 .

\section{Discussion: \\ Determination of minimum effective dosage (MED) of Ovaprim:}

It was observed that hatching rate (\%) varied from rainwater to bore-well water. During this study, a negatively significant relation between fecundity and fertilization rate (\%) with ovaprim doses (Table-4.5, Table-4.7) at $1 \%$ level significance was found. There was inverse linear relation between fecundity and fertilization rate (\%) with different doses (Fig. 4.6 and Fig.4.8).

It was observed that, response time of spawning was varied with different doses of ovaprim and there was a significant correlation between them (Table-4.6, Fig. 6). After different doses ( $\mathrm{ml} / \mathrm{kg}$ of body weight) of Ovaprim injection, breeding behavior of angelfish was observed in laboratory condition (Table 4). At higher doses ( 0.55 and $0.5 \mathrm{ml} / \mathrm{kg}$ of body weight) spawning response time was higher, fertilization rate was lower. Few number of eggs were laid in the dose @ $0.5 \mathrm{ml} / \mathrm{kg}$ of Ovaprim. But, it was observed that complete spawning occurred at the dose @ $0.35 \mathrm{ml} / \mathrm{kg}$ of body weight. Das et al., (1994) injected $0.35 \mathrm{ml} / \mathrm{kg}$ of body weight of a mature female's tawes (Puntius javanicus) and get better spawning within 4-5 hrs. Fish spawned within 6.65 hours (Average spawning time) after the injection. A single dose of Ovaprim yielding about $665.66 \mathrm{eggs}(\mathrm{n}=3)$ and fertilization rate was higher (95\%). So, the ideal dose of ovaprim was $0.35 \mathrm{ml} / \mathrm{kg}$ of body weight for angelfish. Similar results of successful spawning through a single dose of Ovaprim have been reported in several carp species in India (Nandeesha et al. 1990; Das et al. 1994). Nandeesha et al., (1990), (1993); Alok et al., (1993) observed that fertilization rate (\%) and hatching rate (\%) increased using Ovaprim. The highest percentage of fertilization (95-98\%) was observed in ovaprim-injected C. striatus. Azad and Shimray (1991) was observed $90 \%$ fertilization in mrigal, injected with ovaprim. Nayak, P.K.; Mishra, T.K.; Singh B.N; Pandey, A.K. and Das, R.C., (2001) reported that reported that use of Ovaprim cause increase in fertilization and hatching rate (\%) of eggs in Heteropneustes fossilis.

\section{References:}

[1]. Alok D., T. Krishnan, G.P. Talwar, L.C. Garg., 1993. Induced spawning of catfish Heteropneustes fossilis (Bloch), using D-Lys super (6) salmon gonadotropin releasing hormone analog. Aquaculture 115, 159-167.

[2]. Azad, I.S. and D.K. Shimray., 1991. First success in induced breeding of Indian and exotic carps in Manipur using Ovaprim-c. Fishing Chimes. 10, 28-29.

[3]. Chattopadhyay, N.R., 2003. Breeding of ornamental fish (Egg layer). In: Compendium on ornamental fish farming (state level collaboration training course), Directorate of Extension, Ministry of Agriculture; WBUAFS, PP-46.

[4]. Das, R.N., 2003. Ornamental fish breeding cum rearing. In: Compendium on ornamental fish farming (state level collaboration training course), Directorate of Extension, Ministry of Agriculture; WBUAFS, PP. 43-45.

[5]. Das, S.K., Bhattacharjya, B.K. and Sarma, K., 1994. Induced spawning and hatching of Tawes, Puntius javanicus (Bleeker).

[6]. Nandeesha, M.C., Rao, K.G., Jayanna, R. N., Parker, N.C., Varghese, T.G., Keshavanath, P., and Shetty, H.P.C., 1990. Induced spawning of Indian major carps through single application of Ovaprim-C. Proc. of the second Asian fisheries forum. Tokyo, Japan. 581-585.

[7]. Nayak, P.K.; Mishra, T.K.; Singh B.N; Pandey, A.K. and Das, R.C., 2001. Induced maturation and ovulation in Heteropneustes fossilis by using LHRHa, pimozide and Ovaprim for production of quality eggs and larvae. Indian J.Fish. 48 (3), 269-275. 